\title{
Reduced Binding and Phagocytosis of Pneumocystis carinii by Alveolar Macrophages from Persons Infected with HIV-1 Correlates with Mannose Receptor Downregulation
}

\author{
Henry Koziel, ${ }^{\star}$ Quentin Eichbaum, ${ }^{\ddagger}$ Benjamin A. Kruskal, ${ }^{\ddagger}$ Paula Pinkston, ${ }^{\star}$ Rick A. Rogers, ${ }^{\S}$ Martine Y.K. Armstrong, \\ Frank F. Richards, " Richard M. Rose," and R. Alan B. Ezekowitz ${ }^{\ddagger}$ \\ *Division of Pulmonary and Critical Care Medicine, Department of Medicine, Beth Israel Deaconess Medical Center and Harvard \\ Medical School, Boston, Massachusetts 02215; ${ }^{\ddagger}$ Laboratory of Developmental Immunology, Department of Pediatrics, Massachusetts \\ General Hospital, and Harvard Medical School, Boston, Massachusetts 02215; ${ }^{\S}$ Respiratory Biology Program, Department of \\ Environmental Health, Harvard School of Public Health, Boston, Massachusetts 02115; "MacArthur Center for Molecular Parasitology \\ and Pulmonary Critical Care Section, Department of Internal Medicine and Department of Epidemiology and Public Health, Yale \\ University School of Medicine, New Haven, Connecticut 06510; and "Stem Cells, Inc., La Jolla, California 92067
}

\begin{abstract}
The macrophage mannose receptor, a pattern recognition molecule and component of innate immunity, mediates binding and phagocytosis of Pneumocystis carinii and likely represents an important clearance mechanism in the lungs of immunocompetent hosts. The purpose of this study was to examine the ability of alveolar macrophages from HIVinfected individuals to bind and phagocytose $P$. carinii, and to investigate the role of the macrophage mannose receptor in mediating this interaction. Compared with healthy individuals, alveolar macrophage phagocytosis of $P$. carinii from $\mathrm{HIV}^{+}$persons was reduced up to $74 \%(P=0.02)$, primarily reflecting a reduction in the number of organisms associated with each macrophage $(P=0.019)$. Furthermore, macrophages from $\mathrm{HIV}^{+}$individuals demonstrated up to an $80 \%(P<0.05)$ reduction in mannose receptor surface expression and endocytosis. Mannose receptor affinity was unaltered, and mRNA levels were modestly reduced $(P<$ 0.05). Cells from $\mathrm{HIV}^{+}$individuals with $\mathrm{CD}^{+}$counts $<200$ cells $/ \mathrm{mm}^{3}$ (representing individuals at high clinical risk for $P$. carinii pneumonia) demonstrated the lowest levels of $P$. carinii phagocytosis and mannose receptor endocytosis. In vitro HIV infection of alveolar macrophages from healthy individuals reduced mannose receptor endocytosis to $53.2 \%$ $(P<0.05)$ and $P$. carinii binding and phagocytosis to $67.4 \%$ $(P<0.05)$ of control. Our studies suggest that HIV infection may alter innate immunity in the lungs, and that impaired alveolar macrophage mannose receptor-mediated binding and phagocytosis of $P$. carinii may contribute to the susceptibility of HIV-infected individuals to this opportunistic pulmonary pathogen. (J. Clin. Invest. 1998. 102:1332-1344.) Key words: alveolar macrophages - mannose receptor $\bullet$ innate immunity $\bullet P$. carinii $\bullet \mathrm{HIV}-1$
\end{abstract}

Address correspondence to Henry Koziel, M.D., Division of Pulmonary and Critical Care Medicine, Palmer Building, Room 108, Beth Israel Deaconess Medical Center, West Campus, One Deaconess Road, Boston, MA 02215. Phone: 617-632-8255; FAX: 617-632-8253; E-mail: hkoziel@bidmc.harvard.edu

Received for publication 5 May 1997 and accepted in revised form 29 July 1998.

J. Clin. Invest.

(C) The American Society for Clinical Investigation, Inc. 0021-9738/98/10/1332/13 \$2.00

Volume 102, Number 7, October 1998, 1332-1344

http://www.jci.org

\section{Introduction}

Pneumocystis carinii pneumonia remains a frequent and serious opportunistic infection in persons with HIV-1 infection (1, 2 ). Despite the high incidence of $P$. carinii pneumonia in HIVinfected persons, the mechanism(s) of host susceptibility to $P$. carinii are only partially understood. A reduction in circulating peripheral $\mathrm{CD}^{+} \mathrm{T}$ lymphocytes to $<200$ cells $/ \mathrm{mm}^{3}$ identifies HIV-infected individuals at high risk for developing $P$. carinii pneumonia $(3,4)$. The importance of $\mathrm{CD}^{+} \mathrm{T}$ lymphocytes is further supported by the CD4 T lymphocyte-depleted (5) and SCID $(6,7)$ murine models of $P$. carinii pneumonia. However, the role of other pulmonary immune cells, such as alveolar macrophages, in T lymphocyte-mediated resistance to $P$. carinii has not been investigated fully.

Alveolar macrophages account for $>85 \%$ of the lung immune cells and are key effector cells in first line host defense against numerous pulmonary pathogens (8). The importance of alveolar macrophages in the host response to $P$. carinii is supported by several observations in animal models of $P$. carinii pneumonia. Rats selectively depleted of alveolar macrophages are susceptible to exogenous $P$. carinii pneumonia (9). Resolution of $P$. carinii pneumonia in the corticosteroidtreated rat model (10), CD4 T lymphocyte-depleted mouse model (5), and reconstituted SCID mouse model of $P$. carinii pneumonia $(6,7)$ is associated with an influx of alveolar macrophages and release of macrophage-derived cytokines (11). In vitro exposure of normal macrophages to $P$. carinii results in release of oxygen radicals $(12,13)$, and phagocytosis is followed by rapid digestion of the organisms $(14,15)$. These observations suggest an important role for the alveolar macrophage in the successful host response to $P$. carinii.

Prior investigations have provided important insights into the mechanism of interaction of $P$. carinii with alveolar macrophages. Normal human and rodent alveolar macrophages are capable of binding and phagocytosis of $P$. carinii $(12,14$ 18 ), and phagocytosis results in rapid elimination of the organisms. Binding may in part be mediated via fibronectin (16), and phagocytosis may be facilitated by immunoglobulin $(14,18)$.

Recent studies demonstrated that the alveolar macrophage mannose receptor functions as an important receptor in the recognition of $P$. carinii (12). The mannose receptor is a $165-$ $\mathrm{kD}$ transmembrane C-type lectin, expressed on terminally differentiated tissue macrophages (i.e., not circulating blood monocytes). This pattern recognition molecule contains eight tandem extracellular carbohydrate recognition domains (19) capable of recognizing mannose, fucose, galactose, and other simple sugars $(20,21)$, and mediates endocytosis and phagocy- 
tosis. Cell surface redistribution or competitive inhibition of alveolar macrophage mannose receptors reduced binding and phagocytosis of $P$. carinii up to $90 \%$ (12). This opsonin-independent mechanism involves interaction of the mannose-rich glycoprotein surface of $P$. carinii (22) with the receptor (23). The ability of the macrophage mannose receptor to recognize specific carbohydrates present on the surface of $P$. carinii and on a broad range of other potential pathogens (24-26) identifies the mannose receptor as an important component of first line host defense in the early innate cellular immune response to infectious challenge in the lungs.

The integrity of alveolar macrophage effector cell function against $P$. carinii in persons infected with HIV is not known. With the loss of the important regulatory function of $\mathrm{CD}^{+} \mathrm{T}$ lymphocytes which characterizes advanced HIV infection, alterations in alveolar macrophage-mediated phagocytosis of $P$. carinii could impair an effective response to $P$. carinii and contribute to the susceptibility to pneumonia. Alveolar macrophages can be infected with HIV-1 (27), and several abnormalities of monocyte-macrophage effector cell function have been described in the setting of HIV infection (28-31). However, the effector cell function of alveolar macrophages from HIVinfected individuals against $P$. carinii and the specific role of the macrophage mannose receptor in this interaction have not been studied previously.

The purpose of this study was to investigate the ability of human alveolar macrophages to bind and phagocytose $P$. carinii in vitro, comparing cells from healthy individuals to cells from HIV-infected individuals. These studies focused on the role of the macrophage mannose receptor in mediating this host cell-pathogen interaction. Studies were designed to examine alveolar macrophages from HIV-seropositive individuals at low clinical risk for $P$. carinii pneumonia (persons with peripheral $\mathrm{CD}^{+} \mathrm{T}$ lymphocyte counts $>200$ cells $/ \mathrm{mm}^{3}$ ), at high clinical risk for $P$. carinii pneumonia (persons with peripheral $\mathrm{CD}^{+} \mathrm{T}$ lymphocyte counts $<200$ cells $/ \mathrm{mm}^{3}$ ), and from HIV-seropositive persons with active $P$. carinii pneumonia. We observed that alveolar macrophages isolated from HIV-infected persons exhibited reduced binding and phagocytosis of P. carinii and downregulation of mannose receptor expression. The reduction in $P$. carinii phagocytosis and mannose receptor downregulation correlated in part with the clinical severity of HIV-related disease as measured by peripheral CD4 ${ }^{+} \mathrm{T}$ lymphocyte counts. Furthermore, in vitro HIV-1 infection of alveolar macrophages from healthy individuals resulted in reduced mannose receptor endocytosis and $P$. carinii phagocytosis. These findings identify a specific alteration in alveolar macrophage effector cell function which may contribute to the susceptibility of HIV-infected individuals to $P$. carinii pneumonia. Furthermore, this is the first observation that HIV infection may impair cellular components of innate immunity $(24,26,32,33)$ in the lungs.

\section{Methods}

\section{Study subjects}

Prospectively recruited healthy HIV seronegative, and asymptomatic HIV seropositive individuals were without evidence for active pulmonary disease and had normal spirometry. Healthy individuals were without known risk factors for HIV infection and confirmed to be HIV-seronegative by ELISA (ELISA performed according to the manufacturer's instructions; Abbott Diagnostics, North Chicago, IL).
Demographic characteristics for all participants were recorded on standardized forms, and included age, sex, smoking status, HIV risk factor, medical history, and prescribed medications. All HIV-seropositive individuals were further characterized by peripheral CD4 $\mathrm{T}$ lymphocyte counts and the presence or absence of AIDS-defining conditions, including prior remote episodes of $P$. carinii pneumonia.

The asymptomatic HIV-seropositive individuals were further identified as either low or high clinical risk for P. carinii pneumonia based on peripheral CD4 T lymphocyte counts. These two groups included the $\mathrm{HIV}^{+} \mathrm{CD} 4>200$ group, representing HIV-seropositive individuals with peripheral CD $4^{+} \mathrm{T}$ lymphocyte counts $>200$ cells $/ \mathrm{mm}^{3}$ (considered at low risk for $P$. carinii pneumonia) and the $\mathrm{HIV}^{+}$ CD $4<200$ group, representing those with peripheral $\mathrm{CD}^{+}{ }^{+} \mathrm{T}$ lymphocyte counts $<200$ cells $/ \mathrm{mm}^{3}$ (considered at high clinical risk for $P$. carinii pneumonia $[3,4])$.

Additionally, bronchoscopy specimens from HIV-seropositive individuals with active $P$. carinii pneumonia were examined. In this third HIV-seropositive group, $\mathrm{HIV}^{+} \mathrm{PCP}^{+}$, bronchoalveolar lavage $(\mathrm{BAL})^{1}$ cells were obtained from clinical specimens of individuals undergoing diagnostic bronchoscopy for high clinical suspicion of $P$. carinii pneumonia. For this particular population, only that portion of the BAL specimen which remained after diagnostic clinical use was available for the current studies. The diagnosis of $P$. carinii pneumonia was established by the demonstration of typical organisms by immunofluorescent staining using monoclonal antibodies (Genetic Systems, Sanofi Diagnostics Pasteur, Redmond, WA). There was no evidence for bacterial coinfection in any of the BAL specimens.

\section{Bronchoscopy}

Pulmonary immune cells were obtained by BAL using a standard technique (34). All procedures were performed on consenting adults following protocols approved by the Beth Israel Deaconess Medical Center Institutional Review Board. In brief, after topical 2\% lidocaine anesthesia to the oropharynx, a fiberoptic bronchoscope was passed into the airways and wedged in a segment of the right middle lobe. BAL was performed by instilling 6-8 50-ml aliquots of warm nonbacteriostatic normal saline $(0.9 \%)$, followed by gentle suction after each aliquot was infused. The cells were separated from the pooled BAL fluid by centrifugation at $100 \mathrm{~g}$ for $10 \mathrm{~min}$ at $4^{\circ} \mathrm{C}$, washed in cold media RPMI 1640 supplemented with penicillin $100 \mathrm{U} / \mathrm{ml}$ and streptomycin $100 \mu \mathrm{g} / \mathrm{ml}$ (Sigma Chemical Co., St. Louis, MO), and counted on a hemacytometer. Slides for cell morphology and differential determination were prepared by cytocentrifugation (Shandon, Pittsburgh, PA), stained by the modified-Giemsa method (Diff-Quik; Sigma), and examined by light microscopy.

\section{Alveolar macrophages}

Alveolar macrophages were isolated by adherence to plastic bottom tissue culture plates $\left(5.0-7.5 \times 10^{5}\right.$ cells/well $)$ or $13-\mathrm{mm}$ round glass coverslips $\left(2.5 \times 10^{5}\right.$ cells/slip $)$ for $2 \mathrm{~h}$, washed to remove nonadherent cells, and maintained overnight in endotoxin-free complete culture media (RPMI 1640 supplemented with 10\% heat-inactivated FCS [JRH Biosciences, Lanexa, KS], penicillin $100 \mathrm{U} / \mathrm{ml}$, streptomycin $100 \mu \mathrm{g} / \mathrm{ml}$, and amphotericin-B and L-glutamine $2 \mathrm{mM}$ [Sigma]) at $37^{\circ} \mathrm{C}$ in $5 \% \mathrm{CO}_{2}$.

Isolation of alveolar macrophages from all healthy and HIVseropositive persons yielded cells which were $\geq 98 \%$ viable as determined by trypan blue dye exclusion, and demonstrated $>95 \%$ positive nonspecific esterase staining. By light microscopy, no apparent differences in morphology or adherence were identified comparing cells from healthy individuals to cells from HIV-seropositive individuals.

1. Abbreviations used in this paper: BAL, bronchoalveolar lavage; CAI, cell association index; RFU, relative fluorescence units. 


\section{Assessment of alveolar macrophage phagocytic function}

To assess general macrophage function, alveolar macrophages from healthy and HIV-infected individuals were assayed for the ability to ingest latex beads and antibody-coated erythrocytes. Alveolar macrophages on glass coverslips were incubated with FITC-labeled latex beads ( $1 \mu \mathrm{m}$ diameter; Polysciences, Inc., Warington, PA) at a multiplicity of $20: 1$ (beads/macrophages) for $60 \mathrm{~min}$ at $37^{\circ} \mathrm{C}$ in $5 \% \mathrm{CO}_{2}$. Noningested beads were removed by washing, and the adherent cells were fixed overnight in $4 \%$ paraformaldehyde. For each determination performed in duplicate, the number of latex beads associated per 200 macrophages was counted on at least two separate slides by epifluorescence microscopy. Data were expressed as the cell association index (CAI), representing the number of beads bound to or phagocytosed per 100 alveolar macrophages.

Immunoglobulin $(\mathrm{Fc})$ receptor function was assessed by the ability to phagocytose antibody-coated human erythrocytes. $\mathrm{Rh}^{+}$human erythrocytes from healthy HIV-seronegative donors were incubated with or without microRhogam (1:200 dilution) (Children's Hospital Medical Center Blood Bank) in PBS at $37^{\circ} \mathrm{C}$ for $30 \mathrm{~min}$, washed in PBS, and incubated with alveolar macrophage monolayers at a multiplicity of 20:1 (erythrocyte/macrophage), for $60 \mathrm{~min}$ at $37^{\circ} \mathrm{C}$ in $5 \%$ $\mathrm{CO}_{2}$. The macrophages were washed to remove nonadherent erythrocytes, nonphagocytosed erythrocytes were lysed with hypotonic saline for $5 \mathrm{~min}$ at $21^{\circ} \mathrm{C}$, and the cells were fixed overnight in $4 \%$ paraformaldehyde. For each experimental condition performed in duplicate, the number of phagocytosed erythrocytes per 200 macrophages was counted on at least two separate slides by light microscopy. Data were expressed as a phagocytic index, representing the number of erythrocytes phagocytosed per 100 alveolar macrophages.

\section{Pneumocystis carinii organisms}

Male Sprague-Dawley rats (Hilltop Laboratory Animals, Scotsdale, PA) were immunosuppressed by adding dexamethasone $(1 \mathrm{mg} / \mathrm{ml})$ to the drinking water and maintained on low-protein $(8 \%)$ normocaloric diets as described previously (35-37). After 8-12 wk, the animals were killed with intraperitoneal Nembutal, the lungs were aseptically removed, chopped, and filtered through sterile wire mesh, and $P$. carinii organisms were isolated by differential centrifugation. The organisms were placed in complete culture media (Hepes-buffered MEM supplemented with $10 \%$ heat-inactivated FCS, MEM nonessential amino acids, MEM sodium pyruvate, penicillin $100 \mathrm{U} / \mathrm{ml}$, streptomycin $100 \mu \mathrm{g} / \mathrm{ml}$, amphotericin-B and glutamine $2 \mathrm{mM}$ [Cellgro Mediatech, Washington, DC]) over an adherent mink lung fibroblast feeder cell monolayer (MV 1 Lu, ATCC CCL64) (35). After $6 \mathrm{~d}$, the P. carinii organisms were isolated from the culture supernatants by centrifugation at $1,300 \mathrm{~g}$, washed with PBS, and counted on a hemacytometer by light microscopy. Morphology was verified by modified Giemsa stain (which stains the trophozoite and cyst form nuclei), and by Toluidine blue $\mathrm{O}$ stain (which stains the cyst forms). These mixed-life cycle preparations yielded $\sim 90 \%$ trophozoite and $10 \%$ cyst forms. Viability of preparations were measured as $>85 \%$ as determined by dual fluorescence staining detection using flow cytometry (38). These preparations were $>98 \%$ free of contaminating host cells. $P$. carinii preparations visibly contaminated by other microorganisms or as determined by routine microbiological culture were excluded. $P$. carinii preparations were endotoxin-free $(<1.0$ endotoxin units $/ \mathrm{ml})$ as determined by E-toxate Limulus polyphemus assay (Sigma).

\section{FITC labeling of P. carinii}

To facilitate the identification of $P$. carinii in macrophage phagocytosis studies, organisms were labeled with FITC (Sigma), as described previously (12). In brief, suspensions of $P$. carinii were incubated with freshly prepared FITC $(0.1 \mathrm{mg} / \mathrm{ml}$ in PBS at $\mathrm{pH} 7.4)$ for $30 \mathrm{~min}$ at $37^{\circ} \mathrm{C}$. After centrifugation at $1,300 \mathrm{~g}$ for $20 \mathrm{~min}$, the pellet was washed four times with PBS to remove unbound FITC. The FITC-labeled $P$. carinii were enumerated by direct visualization on a hemacytometer with epifluorescence microscopy. The FITC labeling process stained both trophozoite and cyst form surfaces uniformly, and did not affect organism viability as determined by flow cytometry (38).

\section{Assays for determining macrophage binding and phagocytosis} of P. carinii

Alveolar macrophages adherent to round glass coverslips were incubated with FITC-labeled $P$. carinii at an organism to cell ratio of 10:1 for $60 \mathrm{~min}$ at $37^{\circ} \mathrm{C}$ in $5 \% \mathrm{CO}_{2}$. After washing with HBSS containing magnesium and calcium $\left(\mathrm{HBSS}^{+}\right.$), the alveolar macrophage monolayers were fixed in $4 \%$ paraformaldehyde overnight at $4^{\circ} \mathrm{C}$, and two independent methods were used to measure the interaction of $P$. carinii organisms with the alveolar macrophages.

High contrast differential interference (Nomarski) and epifluorescence microscopy. This method determined the total number of $P$. carinii organisms associated with the macrophages. Epifluorescence microscopy allowed the discrimination of cell-associated FITC-labeled $P$. carinii from other macrophage inclusions. Glass coverslips containing the fixed adherent cells and associated organisms were washed in PBS, inverted onto a glass slide with $90 \%$ glycerol in $10 \mathrm{mM}$ TRIS buffer, and sealed. For each experimental condition performed in duplicate, the number of FITC-labeled organisms bound to or phagocytosed per 200 macrophages was counted on at least two separate slides. Data were expressed as (a) the percentage of alveolar macrophages with adherent or ingested organisms; $(b)$ the mean number of adherent or ingested $P$. carinii per individual macrophage engaging organisms; and (c) the CAI, representing the number of organisms bound to or phagocytosed per 100 alveolar macrophages.

Confocal microscopy. This technique allowed for the discrimination of FITC-labeled $P$. carinii phagocytosed by the macrophages from those only bound to the surface. Round glass coverslips with fixed adherent macrophages and FITC-labeled $P$. carinii were counterstained with Nile red $(10 \mathrm{ng} / \mathrm{ml})(39,40)$, washed in PBS, then sealed in micro well chambers and examined using a Sarastro 2000 confocal laser scanning microscope (Molecular Dynamics, Sunnyvale, CA) fitted with a $25 \mathrm{~mW}$ argon-ion laser. The microscope was configured for dual channel fluorescent imaging, and operating parameters for these experiments included $488 / 514 \mathrm{~nm}$ excitation, $535 \mathrm{~nm}$ primary beam splitter, $10 \%$ laser transmission, and $18 \mathrm{~mW}$ laser power. A $595 \mathrm{~nm}$ secondary beam splitter directed fluorescent light emitted from the Nile red-stained cells to a photo multiplier tube fitted with a 600 long pass filter. Short wavelength light $(<595 \mathrm{~nm})$ emitted from the FITC- $P$. carinii was directed to a second photomultiplier tube fitted with a $540 \pm 15 \mathrm{~nm}$ band pass filter. Recorded image pairs were presented as color anaglyph images with macrophages appearing red, and FITC-P. carinii appearing yellow-green. Using this procedure, the position of internalized or surface bound $P$. carinii was determined on an individual cell basis.

For the quantitative assessment, several fields of macrophages were examined at a magnification of 100 under epifluorescent conditions to verify satisfactory and uniform application of the fluorescence label, and to verify that coverslips contained an optimal cell density of $\sim 25$ macrophages per field. This procedure eliminated possible experimental bias due to unintentional selection of fields containing more (or less) $P$. carinii organisms. For image collection and analysis, new fields were then selected using bright field microscopy, and then examined under confocal imaging conditions. To minimized fading effects of the fluorochrome, the laser output was attenuated to $90 \%$ transmittance. Optical sections were obtained $1 \mu \mathrm{m}$ from the coverslip surface to provide a uniform position of focus for the quantitative analysis. This plane of focus was selected because nuclear profiles of individual cells were clearly observed. An estimate of phagocytosis of $P$. carinii was obtained by counting the number of organisms within the confines of the macrophage cytoplasmic membrane and at the level of the nuclear profile of the macrophage. Profiles of at least 100 cells per condition were counted and scored for the presence of FITC-P. carinii as follows: $(a)$ bound to the macrophage surface; $(b)$ phagocytosed; $(c)$ surface bound and phagocytosed; or $(d)$ no cell-associated FITC-P. carinii. Estimates of automated 
quantitation were confirmed by direct visual counting and compared with the confocal images. Data were expressed as the phagocytic index, representing the number of phagocytosed $P$. carinii organisms per 100 macrophages.

\section{Flow cytometry determination of mannose receptor} surface expression

Analysis of macrophage mannose receptor surface density was performed on specimens of BAL cell suspensions on an Epics Profile II flow cytometer (Coulter Electronics, Hialeah, FL). The instrument was calibrated daily with standardized fluorescent particles (Immunocheck; AMAC, Inc., Westbrook, ME). Using a laser power of 5.76 $\mathrm{mW}$, forward light scatter (measuring cell size), right-angle (side) scatter (measuring cell granularity), and two fluorescent signals were measured simultaneously in list-mode. Fluorescence was measured using appropriate photomultiplier tubes and optical filters, using 525 $\mathrm{nm}$ bandpass filter (for FITC detection) with a $40 \mathrm{~nm}$ bandwidth, and a $575 \mathrm{~nm}$ bandpass filter (for phycoerythrin detection) with a $30 \mathrm{~nm}$ bandwidth. The fluorescence of the cells was expressed as the mean of the log fluorescence intensity of the cell population within the analyzed field and the results recorded as mean relative fluorescence units (RFU).

The alveolar macrophages were first identified on the basis of characteristic forward and right angle (side)-scatter properties, and confirmed by staining positive for HLA-DR using an FITC-primary labeled murine anti-human HLA-DR antibody, and negative staining for dual-labeled CD14/CD45 (AMAC, Inc.). This population was then examined for the binding of anti-human mannose receptor antibody. A polyclonal goat anti-human mannose receptor antibody (the generous gift of Dr. Phil Stahl, Department of Physiology and Cell Biology, Washington University, St. Louis, MO) was used as a primary antibody, and an FITC-conjugated swine anti-goat IgG was used as a secondary antibody (Biosource Int., Camarillo, CA). In brief, $5 \times 10^{5}$ freshly isolated BAL cells in $\mathrm{HBSS}^{+}$were sequentially incubated with the primary antibody (1:200 dilution) for $60 \mathrm{~min}$, then the secondary antibody $(1: 500)$ for $30 \mathrm{~min}$ at $4^{\circ} \mathrm{C}$. The cell pellet was then resuspended in OptiLyse-C (AMAC, Inc.), a commercial fixative containing formalin, and maintained at $4{ }^{\circ} \mathrm{C}$ overnight for the purpose of inactivating HIV (41). Samples were prepared and analyzed in duplicate, and a minimum of 5,000 cells was counted for each sample. For each sample, the proportion of cells staining positive and a mean $\log$ fluorescence value were determined for the population of cells. Nonspecific binding of the FITC-conjugated secondary antibody was $<15 \%$, and was subtracted from the mean fluorescence. For the purpose of reducing nonspecific binding, all solutions contained $0.1 \%$ BSA.

\section{Determination of macrophage mannose receptor ligand binding and endocytosis}

Mannose receptor function was assessed by ligand binding and endocytosis assays using ${ }^{125}$ I-mannosylated BSA (mannosyl-BSA; E.Y.
Labs, La Jolla, CA), a ligand with a high specificity for the mannose receptor (42). Using $\mathrm{Na}^{125} \mathrm{I}$ (NEN, DuPont, Cambridge, MA), the ligand was prepared by the chloramine-T method (43), eluted on G-25 columns (Pharmacia Biotech, Piscataway, NJ), and concentrations of ligand were determined by TCA precipitation. The specific activity of the ${ }^{125} \mathrm{I}$-mannosyl-BSA was $2.5-4.0 \times 10^{6} \mathrm{cpm} / \mu \mathrm{g}$.

${ }^{125}$ I-mannosyl-BSA was added to alveolar macrophage monolayers in duplicate at a final concentration of $350 \mathrm{nM}$. Mannose receptormediated endocytosis was assessed by incubation at $37^{\circ} \mathrm{C}$ for $20 \mathrm{~min}$, and mannose receptor-mediated binding was assessed by incubation at $4^{\circ} \mathrm{C}$ for $60 \mathrm{~min}$. Determination of mannose receptor affinity was performed in triplicate at $4^{\circ} \mathrm{C}$, with $350 \mathrm{nM}{ }^{125} \mathrm{I}$-mannosyl-BSA, in the presence or absence of increasing concentrations of unlabeled mannosyl-BSA (final concentrations per incubation condition included 0, 5, $10,15,20,50,100$, and $5000 \mathrm{nM}$ unlabeled mannosyl-BSA).

After incubation, cells were washed with ice-cold $\mathrm{HBSS}^{+}$, solubilized in $1 \mathrm{~N} \mathrm{NaOH}$ for $60 \mathrm{~min}$ at $21^{\circ} \mathrm{C}$, and the radioactivity in the solubilized portion from each well was determined by gamma-radiation counter (5500A; Beckman Instruments, Irvine, CA). To control for macrophage cell number, data were normalized by determination of the total protein content for each condition (Biorad Laboratories, Richmond, CA), and the data were expressed as the amount (nanograms) of mannosyl-BSA ligand per $100 \mu \mathrm{g}$ total protein. Nonspecific ligand binding was estimated by the addition of mannan $(1 \mathrm{mg} / \mathrm{ml})$ to identical replicate wells. For the purpose of reducing nonspecific ligand binding, $0.1 \%$ BSA was included in all wells.

\section{Mannose receptor $m R N A$ determination}

Mannose receptor mRNA levels were measured by ribonuclease protection assay. Alveolar macrophage monolayers were solubilized in $4 \mathrm{M}$ guanidine thiocyanate buffer $(\mathrm{pH}=6.0)$, and the total RNA isolated by $5.7 \mathrm{M} \mathrm{CsCl}_{2}$ gradient ultracentrifugation at $35,000 \mathrm{~g}$ at $21^{\circ} \mathrm{C}$ for $21 \mathrm{~h}$. The RNA pellet was suspended in cold $0.3 \mathrm{M}$ sodium acetate buffer $(\mathrm{pH}=6.0)$, precipitated in absolute ethanol at $-70^{\circ} \mathrm{C}$ for $24 \mathrm{~h}$, washed twice with $70 \%$ ethanol, and finally resuspended in DEPCtreated $\mathrm{H}_{2} \mathrm{O}$. Total RNA was estimated by measuring UV spectrophotometer absorbance at $260 \mathrm{~nm}$, and compared with total protein absorbance at $280 \mathrm{~nm}$, the ratio was $>1.7$ for or all samples. The integrity of RNA was confirmed by gel electrophoresis in $1.1 \%$ agarose.

The ribonuclease protection assay was performed by cloning a 258-bp highly specific fragment of the mannose receptor located in the third carbohydrate recognition domain (CRD 3, between bp 1612 and 1870), into the pBluescript SK phagemid. A ${ }^{32} \mathrm{P}$-antisense riboprobe $(800 \mathrm{Ci} / \mathrm{mmol}$; New England Biolabs, Beverly, MA) was generated using T7 polymerase (T3/T7 MASIscript kit No. 1326; Ambion, Inc., Austin, TX). The protection assay was performed on the RNA samples according to the manufacturer's instructions using the Ambion RPAII kit (kit No. 1410; Ambion, Inc.). The dried gel was incubated overnight on a PhosphorImager cassette (Molecular Dynamics) and scanned by densitometry. As an internal control to normalize for differences in total RNA between samples, the assay was per-

Table I. Clinical and Demographic Characteristics of the Study Groups

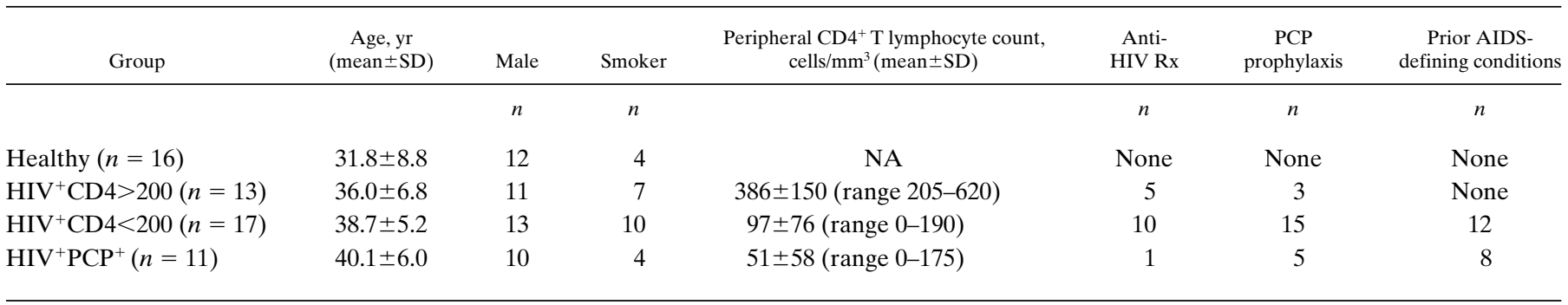

$N A$, not available. 


\begin{tabular}{|c|c|c|c|c|c|}
\hline Group & BAL fluid recovery & $\begin{array}{l}\text { Total BAL cells } \\
\quad\left(\times 10^{6}\right)\end{array}$ & Macrophages & Lymphocytes & Neutrophils \\
\hline & $\%$ & & $\%$ & $\%$ & $\%$ \\
\hline Healthy $(n=16)$ & $67.4 \pm 9.1$ & $32.4 \pm 28.4$ & $97.2 \pm 1.4$ & $2.1 \pm 1.2$ & $0.3 \pm 0.5$ \\
\hline $\mathrm{HIV}^{+} \mathrm{CD} 4>200(n=13)$ & $60.3 \pm 11.3$ & $85.8 \pm 68.1$ & $86.3 \pm 4.4 *$ & $5.0 \pm 6.8$ & $0.2 \pm 0.5$ \\
\hline $\mathrm{HIV}^{+} \mathrm{CD} 4<200(n=17)$ & $61.8 \pm 8.1$ & $51.1 \pm 50.5$ & $85.6 \pm 4.6^{*}$ & $6.3 \pm 4.0^{*}$ & $0.38 \pm 0.5$ \\
\hline $\mathrm{HIV}^{+} \mathrm{PCP}^{+}(n=11)$ & NA & $25.3 \pm 12.5$ & $91.2 \pm 6.8$ & $8.2 \pm 7.2$ & $0.3 \pm 0.3$ \\
\hline
\end{tabular}

Values represent mean \pm SD. $N A$, Not available. $* P<0.05$ compared to healthy.

formed with the simultaneous addition of a radiolabeled probe for $\beta$-actin. Data were expressed as a ratio of mannose receptor mRNA to $\beta$-actin mRNA.

\section{In vitro HIV-1 infection of normal alveolar macrophages}

To assess the direct effect of HIV-1 infection on macrophage mannose receptor function and $P$. carinii binding and phagocytosis, alveolar macrophages from healthy individuals were infected in vitro as previously described (27), using a monocytotropic isolate (HIV Bal). In brief, adherent macrophages were incubated with the isolate $\left(>10^{5}\right.$ pg HIV p24/ml) for $2 \mathrm{~h}$ at $37^{\circ} \mathrm{C}$, washed five times to remove free virus, and maintained in complete culture media for $2 \mathrm{wk}$. Uninfected macrophages were also maintained as control conditions. Culture media was changed every 3-4 d, and productive HIV-1 infection was verified by the measurement of HIV p24 antigen in the culture supernatants by ELISA (DuPont). At 2 wk after HIV-1 infection, viability was determined on representative cells by trypan blue dye exclusion, and mannose receptor endocytosis and $P$. carinii CAI were determined, comparing HIV-1-infected to uninfected alveolar macrophages, as described above.

\section{Statistical analysis}

Experimental conditions were performed in duplicate or triplicate, performed on at least three different occasions using alveolar macrophages from different individuals (except where noted). Results are expressed as mean \pm SEM. Statistical data for comparison of groups were calculated by ANOVA, and paired data groups were compared using Student's $t$ tests using INSTAT2 statistical package (Graphpad Software, San Diego, CA) on an IBM PS/2 120 MB computer (IBM Corp., Armonk, NY). Correlations between P. carinii CAI or mannose receptor endocytosis with peripheral CD4 T lymphocyte counts were calculated with the Pearson test. Statistical significance was accepted for $P \leq 0.05$.

\section{Results}

Participant characteristics and demographics. Bronchoscopies were performed on a total of 16 healthy individuals, including 12 males and 4 females with a mean age of $31.8 \pm 8.8 \mathrm{yr}( \pm \mathrm{SD})$. The ethnic origin included 1 Black and 15 Caucasians. Four used tobacco, and none were using prescribed medications. All tested seronegative for antibodies to HIV by ELISA (data not shown).

Bronchoscopy specimens were obtained on a total of 41 HIV-seropositive individuals, including 34 males and 7 females with a mean age of $38.2 \pm 6.0 \mathrm{yr}$. The ethnic origin included 30 Caucasians, 9 Blacks, and 2 Hispanics. 21 used tobacco. The HIV risk factors included 31 homosexual, 8 intravenous drug use, 1 transfusion related, and 1 heterosexual contact. Prior AIDS-defining conditions included Kaposi's sarcoma, Myco- bacterium avium complex infection, cytomegalovirus infection, or prior remote ( $>3 \mathrm{mo}$ ) episodes of $P$. carinii pneumonia. All were confirmed to be seropositive for antibodies to HIV by ELISA (data not shown).

The demographic characteristics of the four groups are presented in Table I. Of the HIV-seropositive individuals with active $P$. carinii pneumonia, all were receiving anti- $P$. carinii treatment (intravenous TMP-SMX or pentamidine) for $<48 \mathrm{~h}$ at the time of the diagnostic bronchoscopy. None of these individuals received systemic corticosteroids at the time of bronchoscopy.

Bronchoscopy specimen characteristics. Compared with healthy individuals, there was a trend to higher total recovered BAL cells (Table II) and a significant decrease in the proportion of alveolar macrophages for the $\mathrm{HIV}^{+} \mathrm{CD} 4>200$ and $\mathrm{HIV}^{+} \mathrm{CD} 4<200$ groups $(P<0.05)$, and a significant increase in the percentage of alveolar lymphocytes for the $\mathrm{HIV}^{+} \mathrm{CD} 4<200(P<0.05)$.

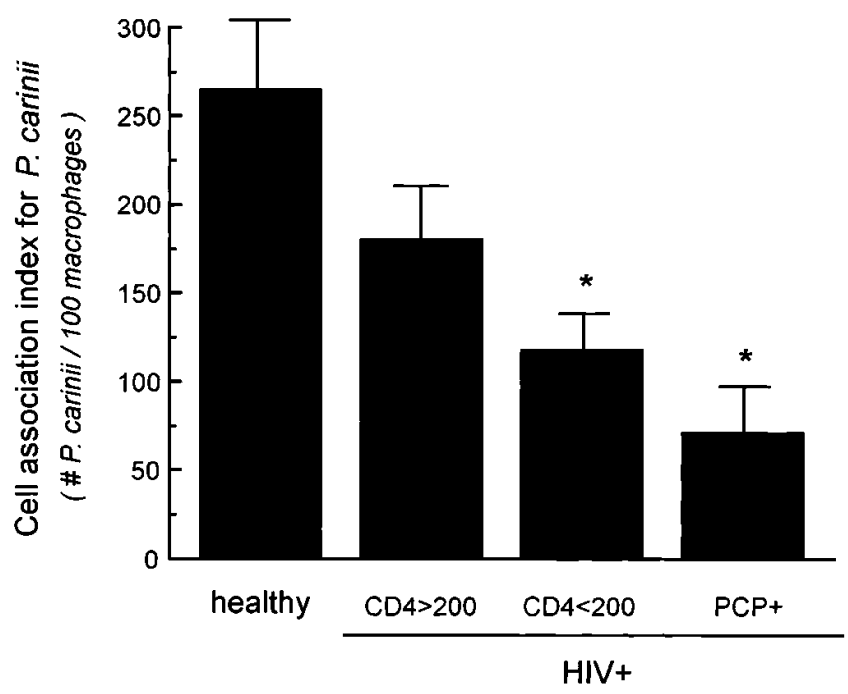

Figure 1. Nomarski and epifluorescence microscopy determination of $P$. carinii binding and phagocytosis by alveolar macrophages. The CAI, representing the number of $P$. carinii organisms bound to the surface or phagocytosed per 100 macrophages, was determined for each group including healthy individuals $(n=13)$, and $\mathrm{HIV}^{+}$individuals with $\mathrm{CD}^{+} \mathrm{T}$ lymphocytes $>200$ cells $/ \mathrm{mm}^{3}(n=10), \mathrm{CD}^{+} \mathrm{T}$ lymphocytes $<200$ cells $/ \mathrm{mm}^{3}(n=12)$, and active $P$. carinii pneumonia $(n=5)$. Samples were prepared in duplicate, and each sample was scored with a minimum examination of 200 cells. Data represent mean value \pm SEM. $* P \leq 0.05$ compared with the healthy group. 

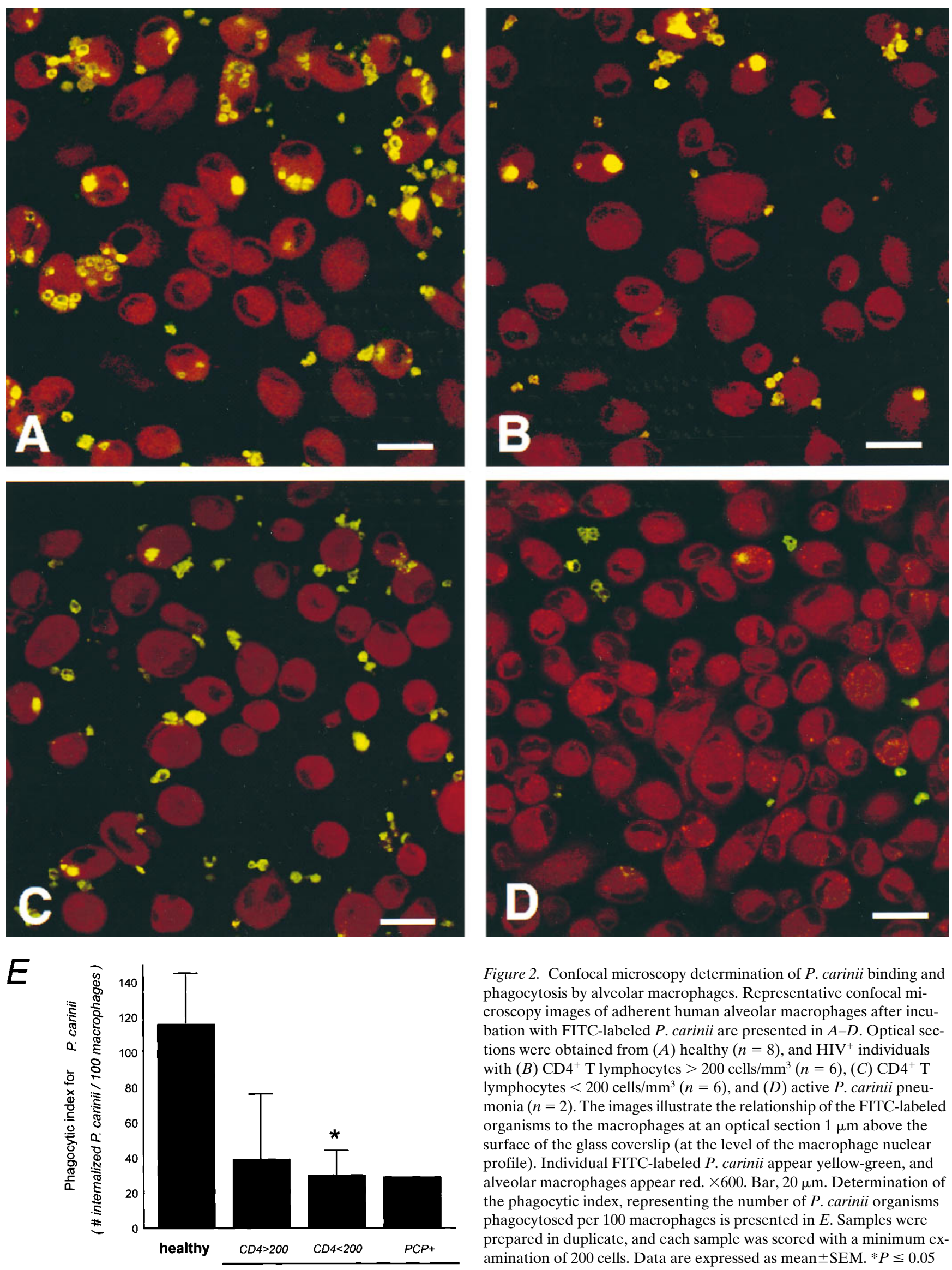

Figure 2. Confocal microscopy determination of $P$. carinii binding and phagocytosis by alveolar macrophages. Representative confocal microscopy images of adherent human alveolar macrophages after incubation with FITC-labeled $P$. carinii are presented in $A-D$. Optical sections were obtained from $(A)$ healthy $(n=8)$, and $\mathrm{HIV}^{+}$individuals with $(B) \mathrm{CD}^{+} \mathrm{T}$ lymphocytes $>200$ cells $/ \mathrm{mm}^{3}(n=6),(C) \mathrm{CD}^{+} \mathrm{T}$ lymphocytes $<200$ cells $/ \mathrm{mm}^{3}(n=6)$, and $(D)$ active $P$. carinii pneumonia $(n=2)$. The images illustrate the relationship of the FITC-labeled organisms to the macrophages at an optical section $1 \mu \mathrm{m}$ above the surface of the glass coverslip (at the level of the macrophage nuclear profile). Individual FITC-labeled $P$. carinii appear yellow-green, and alveolar macrophages appear red. $\times 600$. Bar, $20 \mu \mathrm{m}$. Determination of the phagocytic index, representing the number of $P$. carinii organisms phagocytosed per 100 macrophages is presented in $E$. Samples were prepared in duplicate, and each sample was scored with a minimum examination of 200 cells. Data are expressed as mean \pm SEM. $* P \leq 0.05$ compared with the healthy group. 
Nomarski and epifluorescence microscopy determination of macrophage binding and phagocytosis of P. carinii. A determination of CAI for $P$. carinii was available for 13 healthy and $27 \mathrm{HIV}$-seropositive individuals. Alveolar macrophages from healthy individuals demonstrated a CAI of $265 \pm 44$ (mean \pm SEM) $P$. carinii/100 macrophages (Fig. 1). The CAI for the $\mathrm{HIV}^{+} \mathrm{CD} 4>200$ group was reduced by $32 \%$ to $182 \pm 34$, although this did not achieve statistical significance $(P>0.05)$. However, the CAI for the $\mathrm{HIV}^{+} \mathrm{CD} 4<200$ group was reduced by $56 \%$ to $118 \pm 22(P<0.007)$. For this group, there was no difference in the CAI comparing persons with no prior episodes of $P$. carinii pneumonia $(n=8)(\mathrm{CAI}=$ $129 \pm 24)$ to persons with at least one prior remote episode of $P$. carinii pneumonia $(n=4)(\mathrm{CAI}=112 \pm 66)(P>0.05)$. For the $\mathrm{HIV}^{+} \mathrm{PCP}^{+}$group, the CAI was reduced by $73 \%$ to $70.9 \pm 35(P=0.014)$. The CAI correlated directly with the peripheral CD4 T lymphocyte count, with the Pearson correlation coefficient $(r)=0.3972(P=0.036)$.

In contrast, no significant differences were observed in the capacity of alveolar macrophages from the four groups to ingest latex beads and antibody-coated erythrocytes. The CAI for latex beads, representing actin-independent internalization, was $241 \pm 43$ (mean \pm SEM) for alveolar macrophages from healthy individuals $(n=13)$, compared with $223 \pm 29$ for the $\mathrm{HIV}^{+} \mathrm{CD} 4>200$ group $(n=10), 206 \pm 34$ for the $\mathrm{HIV}^{+} \mathrm{CD} 4<200$ group $(n=12)$, and $194 \pm 41$ for the $\mathrm{HIV}^{+} \mathrm{PCP}^{+}$group $(n=5)(P>0.05$ compared with healthy persons). The phagocytic index for antibody-coated erythrocytes, representing Fc receptor-dependent internalization, was $161 \pm 41$ for alveolar macrophages from healthy individuals $(n=13)$, compared with $147 \pm 38$ for the $\mathrm{HIV}^{+} \mathrm{CD} 4>200$ group $(n=10), 113 \pm 27$ for the $\mathrm{HIV}^{+} \mathrm{CD} 4<200$ group $(n=$ $12)$, and $107 \pm 36$ for the $\mathrm{HIV}^{+} \mathrm{PCP}^{+}$group $(n=5)(P>0.05$ compared with healthy persons).

There were no significant differences in the proportion of alveolar macrophages engaging $P$. carinii organisms. Direct visualization of the cells from healthy individuals revealed that $56.6 \pm 6.8 \%$ (mean \pm SEM) of alveolar macrophages bound and/or phagocytosed at least one organism, compared with $41.6 \pm 6.6 \%$ of the macrophages from the $\mathrm{HIV}^{+} \mathrm{CD} 4>200$ group, $40.6 \pm 6.2 \%$ of the macrophages from $\mathrm{HIV}^{+} \mathrm{CD} 4<200$ group, and $30.7 \pm 11 \%$ of the macrophages from the $\mathrm{HIV}^{+} \mathrm{PCP}^{+}$group $(P>0.05$ compared with healthy individuals).

A significant reduction in the number of $P$. carinii organisms associated with individual alveolar macrophages in the HIV-seropositive groups with advanced disease was observed. Alveolar macrophages from healthy individuals had $4.17 \pm 0.3$ organisms (mean \pm SEM) for each macrophage engaging $P$. carinii (range 1-43) and cells from the $\mathrm{HIV}^{+} \mathrm{CD} 4>200$ group had $3.74 \pm 0.3(P>0.05)$ organisms associated with each macrophage (range 1-14). In contrast, cells from the $\mathrm{HIV}^{+} \mathrm{CD} 4<200$ group had $2.81 \pm 0.3(P=0.002)$ organisms associated with each macrophage (range 1-19), and for the $\mathrm{HIV}^{+} \mathrm{PCP}^{+}$group, alveolar macrophages had $2.51 \pm 0.7(P=$ 0.02) organisms associated with each cell (range 1-15).

Confocal microscopy determination of $P$. carinii binding and phagocytosis. Confocal microscopy imaging data were available for a total of 8 healthy and $14 \mathrm{HIV}$-seropositive individuals. Representative confocal images are provided in Fig. 2, $A-D$. Determination of a CAI for the four groups revealed values proportional to those determined by Nomarski and epi- fluorescence microscopy (data not shown). The CAI values determined by confocal microscopy were lower than those determined by Nomarski and epifluorescence microscopy as the confocal determinations were performed at a single optical section (i.e., not the entire cell). Three-dimensional reconstruction analysis of FITC-P. carinii associated with alveolar macrophages did not reveal differences in the distribution of the organism as a function of height above the coverslip surface (data not shown).

The phagocytic capacity of alveolar macrophages from the HIV seropositive groups with advanced disease was reduced. The phagocytic index for alveolar macrophages from healthy individuals was $116 \pm 27$ (mean \pm SEM) (Fig. $2 E$ ). The phagocytic index for persons in the $\mathrm{HIV}^{+} \mathrm{CD} 4>200$ group was reduced by $66 \%$ to $39.0 \pm 19$, although this was not statistically significant $(P>0.05)$. For the $\mathrm{HIV}^{+} \mathrm{CD} 4<200$ group, the phagocytic index was significantly reduced by $74 \%$ to $30.2 \pm 11$ $(P<0.02)$. In the group $\mathrm{HIV}^{+} \mathrm{PCP}^{+}$, the phagocytic index was reduced by $75 \%$ to $29(n=2)$.

Flow cytometry determination of mannose receptor surface expression. Flow cytometry analysis was available for 12 healthy and $22 \mathrm{HIV}$-seropositive individuals. Representative histograms for the four groups are presented in Fig. 3. For the population of cells identified as macrophages, $98 \%$ exhibited positive staining for HLA-DR for all groups. Both the surface density and the number of macrophages expressing mannose receptor were reduced in the HIV seropositive groups. Quantitative analysis revealed that $98 \%$ of alveolar macrophages from healthy individuals $(n=12)$ expressed mannose receptor, with a surface fluorescence intensity of $9.10 \pm 2.4$ RFU. In comparison, in the $\mathrm{HIV}^{+} \mathrm{CD} 4>200$ group $(n=7) 89 \%$ of cells expressed mannose receptor, and the surface fluorescence in-

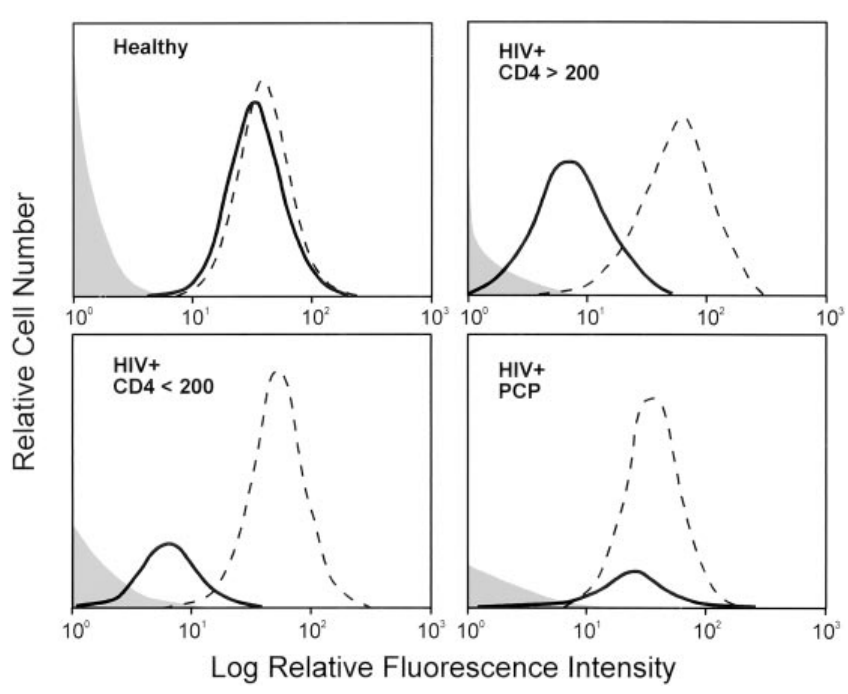

Figure 3. Flow cytometry analysis for surface expression of mannose receptor on alveolar macrophages. Alveolar macrophages were examined from healthy $(n=12)$, and $\mathrm{HIV}^{+} \mathrm{CD}>200(n=7)$, $\mathrm{HIV}^{+} \mathrm{CD} 4<200(n=10)$, and $\mathrm{HIV}^{+} \mathrm{PCP}^{+}(n=5)$ groups. Each panel illustrates a representative flow cytometry profile of one subject for each of the groups examined, demonstrating positive HLA-DR staining (dashed line) and positive mannose receptor antibody staining (solid line), separated from background (shaded curve). The ordinate represents relative cell number and the abscissa represents relative $\log$ fluorescence intensity. 
tensity was reduced to $2.81 \pm 0.6 \mathrm{RFU}(P=0.03)$. For the $\mathrm{HIV}^{+} \mathrm{CD} 4<200$ group $(n=10), 26 \%$ of cells expressed mannose receptor and the surface fluorescence intensity was reduced to $1.25 \pm 0.3 \mathrm{RFU}(P=0.0006)$. The observed value for surface fluorescence intensity for the $\mathrm{HIV}^{+} \mathrm{PCP}^{+}$group $(n=5)$ was $2.56 \pm 0.6 \mathrm{RFU}(P>0.05)$, although only $19 \%$ of cells expressed mannose receptor.

The specificity of the polyclonal anti-mannose receptor antibody was assessed by comparing alveolar macrophages to peripheral blood monocytes (which do not express mannose receptor) in paired blood and BAL specimens from three healthy individuals. Peripheral blood monocytes were identified by characteristic forward scatter and side scatter, and by positive CD14/CD45 dual staining. These monocytes failed to demonstrate positive staining with the polyclonal anti-mannose receptor antibody, whereas the alveolar macrophages from the same individuals demonstrated positive staining (data not shown).

Mannose receptor-mediated endocytosis and ligand binding. Determinations of mannose receptor-mediated endocytosis were available for 12 healthy and 24 HIV-seropositive individuals. Cells from healthy individuals $(n=12)$ demonstrated a value of $52.2 \pm 19 \mathrm{ng}$ ligand (mean \pm SEM) per $100 \mu \mathrm{g}$ protein (Fig. $4 A$ ), and for the $\mathrm{HIV}^{+} \mathrm{CD} 4>200$ group $(n=9)$ a value of $37.3 \pm 14(P>0.05)$. A significant reduction was observed in the $\mathrm{HIV}^{+} \mathrm{CD} 4<200$ group $(n=12)$ to $14.7 \pm 5.5(P=$ $0.045)$. In this group, endocytosis for persons without any prior episodes of $P$. carinii pneumonia demonstrated a value of

$A$
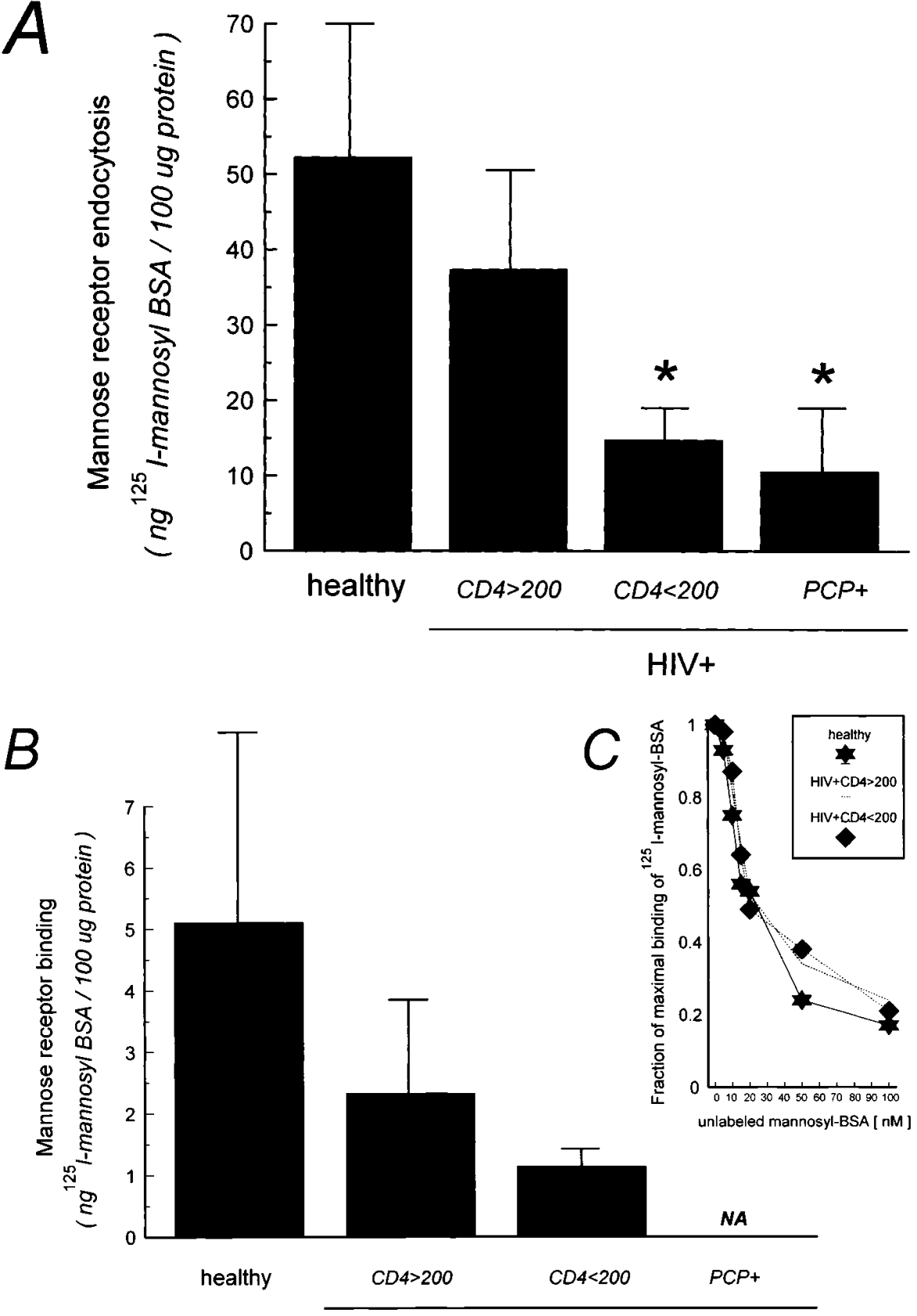

Figure 4. Determination of alveolar macrophage mannose receptor-mediated endocytosis, binding, and affinity. Using ${ }^{125}$ I-mannosyl-BSA as a ligand for the mannose receptor, $(A)$ measurements of alveolar macrophage endocytosis were performed at $37^{\circ} \mathrm{C}$, and $(B)$ mannose receptor binding was performed at $4^{\circ} \mathrm{C}$. $(C)$ For the determination of receptor affinity, each data set is a representative experiment performed from each group including healthy $(n=4), \mathrm{HIV}^{+} \mathrm{CD} 4>200(n=3)$, and $\mathrm{HIV}^{+} \mathrm{CD} 4<200$ groups $(n=5)$. Samples for each condition were performed in triplicate. Data expressed as mean values \pm SEM. $* P \leq 0.05$ compared with the healthy group. 
13.2 $\pm 6.1(n=8)$ compared with $4.7 \pm 2.1(P=0.04)$ from persons with at least one prior episode of $P$. carinii pneumonia $(n=4)$. Endocytosis was also reduced in the $\mathrm{HIV}^{+} \mathrm{PCP}^{+}$ group $(n=3)$ to $3.9 \pm 2.4(P<0.05)$. Endocytosis correlated directly with the peripheral CD4 T lymphocyte count, with the Pearson correlation coefficient $(r)=0.4976(P=0.013)$.

Determinations of mannose receptor-mediated ligand binding were available for 9 healthy and 12 HIV-seropositive individuals. Cells from healthy individuals $(n=9)$ demonstrated a value of $5.11 \pm 2.8 \mathrm{ng}$ ligand per $100 \mu \mathrm{g}$ total protein (Fig. $4 \mathrm{~B}$ ). Although a trend towards reduced binding was observed in the $\mathrm{HIV}^{+}$groups, differences did not achieve statistical significance. In the $\mathrm{HIV}^{+} \mathrm{CD} 4>200$ group $(n=4)$, binding was $2.33 \pm 1.7$, and in the $\mathrm{HIV}^{+} \mathrm{CD} 4<200$ group $(n=8)$ binding was $1.14 \pm 0.35$ ( $P>0.05$ compared with healthy individuals). Data for receptor binding were not available for the $\mathrm{HIV}^{+} \mathrm{PCP}^{+}$group.

Mannose receptor affinity. Determination of the mannose receptor $K_{\mathrm{d}}$ revealed similar values for the three groups evaluated (Fig. $4 \mathrm{C}$ ). The half-maximal inhibition of ${ }^{125}$ I-mannosylBSA binding for alveolar macrophages from healthy individuals occurred at $\sim 20 \mathrm{nM}(n=4)$ of unlabeled mannosyl-BSA (similar to published $K_{\mathrm{d}}$ for the macrophage mannose receptor [44]). Similar values for half-maximal inhibition were observed for both the $\mathrm{HIV}^{+} \mathrm{CD} 4>200$ group $(n=3)$ and the $\mathrm{HIV}^{+} \mathrm{CD} 4<200$ group $(n=5)$. Alveolar macrophages from the $\mathrm{HIV}^{+} \mathrm{PCP}^{+}$group were not available for mannose receptor affinity determination.

Effect of medications on mannose receptor activity. Of the 41 HIV-seropositive individuals evaluated, 32 were taking prescribed medications, with 23 (72\%) taking one or more of the following: zidovudine (AZT), trimethoprim-sulfamethoxazole (TMP-SMX), or aerosolized pentamidine (AP). To assess the potential influence of these drugs on mannose receptor activity, alveolar macrophages from healthy individuals were preincubated with AZT $(1 \mu \mathrm{g} / \mathrm{ml})$, pentamidine $(1 \mu \mathrm{g} / \mathrm{ml})$, or TMPSMX $\left(1 \mu \mathrm{g} / \mathrm{ml}\right.$ of TMP, $8 \mu \mathrm{g} / \mathrm{ml}$ of SMX) for $24 \mathrm{~h}$ at $37^{\circ} \mathrm{C}$ in $5 \% \mathrm{CO}_{2}$ before assessment of mannose receptor activity. The selected concentrations approximated levels reported in BAL fluid (45) and serum $(46,47)$. None of these agents reduced mannose receptor activity as determined by ${ }^{125}$ I-mannosylBSA endocytosis (data not shown).

Measurement of mannose receptor $m R N A$. Mannose receptor mRNA determinations were available for 5 healthy and 12 HIV-infected individuals. Mannose receptor mRNA levels were reduced in cells from persons with HIV infection in the absence of active $P$. carinii pneumonia (Fig. 5). Values for mannose receptor mRNA (expressed as a ratio of mannose receptor mRNA to $\beta$-actin mRNA) disclosed values of 3.7 for healthy individuals $(n=5), 2.4(P=0.029)$ for the $\mathrm{HIV}^{+} \mathrm{CD} 4>200$ group $(n=6)$, and $2.8(P=0.047)$ for the $\mathrm{HIV}^{+} \mathrm{CD} 4<200$ group $(n=6)$. Mannose receptor mRNA determinations for the $\mathrm{HIV}^{+} \mathrm{PCP}^{+}$group were not available.

Comprehensive studies on selected individuals. Examination of five parameters on the cells isolated from four individuals in each of three groups demonstrated that in general the CAI and phagocytic index correlated with mannose receptor surface density, endocytosis, and mRNA levels (Fig. 6). Compared with healthy individuals, a significant reduction in mannose surface density, phagocytic index, and mRNA was observed for the $\mathrm{HIV}^{+} \mathrm{CD} 4>200$ group $(P<0.05)$, and significant reductions in the phagocytic index, surface density, endocytosis, and mannose receptor mRNA for the

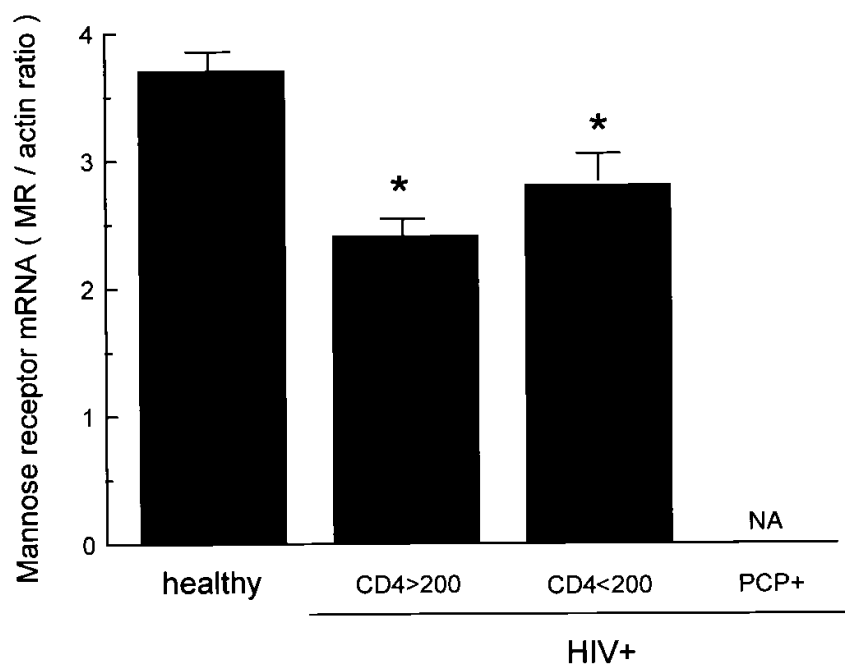

Figure 5. Determination of mannose receptor mRNA. Quantitation of mannose receptor mRNA was normalized and expressed as a ratio of mannose receptor mRNA to $\beta$-actin mRNA. Compared with cells from healthy individuals, mannose receptor mRNA levels were reduced in the alveolar macrophages from the two groups of $\mathrm{HIV}^{+}$individuals studied. Data are expressed as mean values \pm SEM. $* P \leq$ 0.05 compared with the healthy group.

$\mathrm{HIV}^{+} \mathrm{CD} 4<200$ group $(P<0.05)$. Biological variability was observed, especially for the alveolar macrophages from healthy individuals (subjects 1-4 in Fig. 6). No differences were observed comparing smokers to nonsmokers.

Effect of in vitro HIV-1 infection on alveolar macrophage function. In vitro infection of alveolar macrophages from healthy individuals with a monocytotropic HIV isolate (HIV$\mathrm{Bal}$ ) resulted in a productive infection by $2 \mathrm{wk}$ of incubation as determined by elevated HIV-1 p24 levels in the cultured supernatants to $>200 \mathrm{pg}$ p $24 / \mathrm{ml}$. The viability of HIV-1-infected and uninfected macrophages was $\geq 96 \%$ as determined by trypan blue dye exclusion, and no morphological differences were apparent by light microscopy (data not shown). Compared with uninfected cells, mannose receptor endocytosis was reduced to $53.2 \pm 10.1 \%(P<0.05)$ in macrophages infected with HIV-1 (Fig. $7 A$ ), and the CAI for $P$. carinii was reduced to $67.4 \pm 8.2 \%(P<0.05)$ (Fig. $7 B)$.

\section{Discussion}

In this study, alveolar macrophages from HIV-infected individuals exhibited reduced in vitro binding and phagocytosis of $P$. carinii. This reduction correlated with the clinical severity of HIV disease, and was most profound in alveolar macrophages from HIV-seropositive individuals with peripheral $\mathrm{CD}^{+} \mathrm{T}$ lymphocyte counts $<200$ cells $/ \mathrm{mm}^{3}$, representing persons at high clinical risk for $P$. carinii pneumonia. The reduced binding and phagocytosis was attributed to a significant reduction in the number of $P$. carinii organisms associated with each macrophage. This observation did not represent a global impairment in macrophage function as cell morphology, viability, and the capacity to ingest latex beads and IgG-opsonized erythrocytes were comparable to cells from healthy individuals.

Furthermore, mannose receptor expression was downregulated in these same alveolar macrophages which displayed re- 


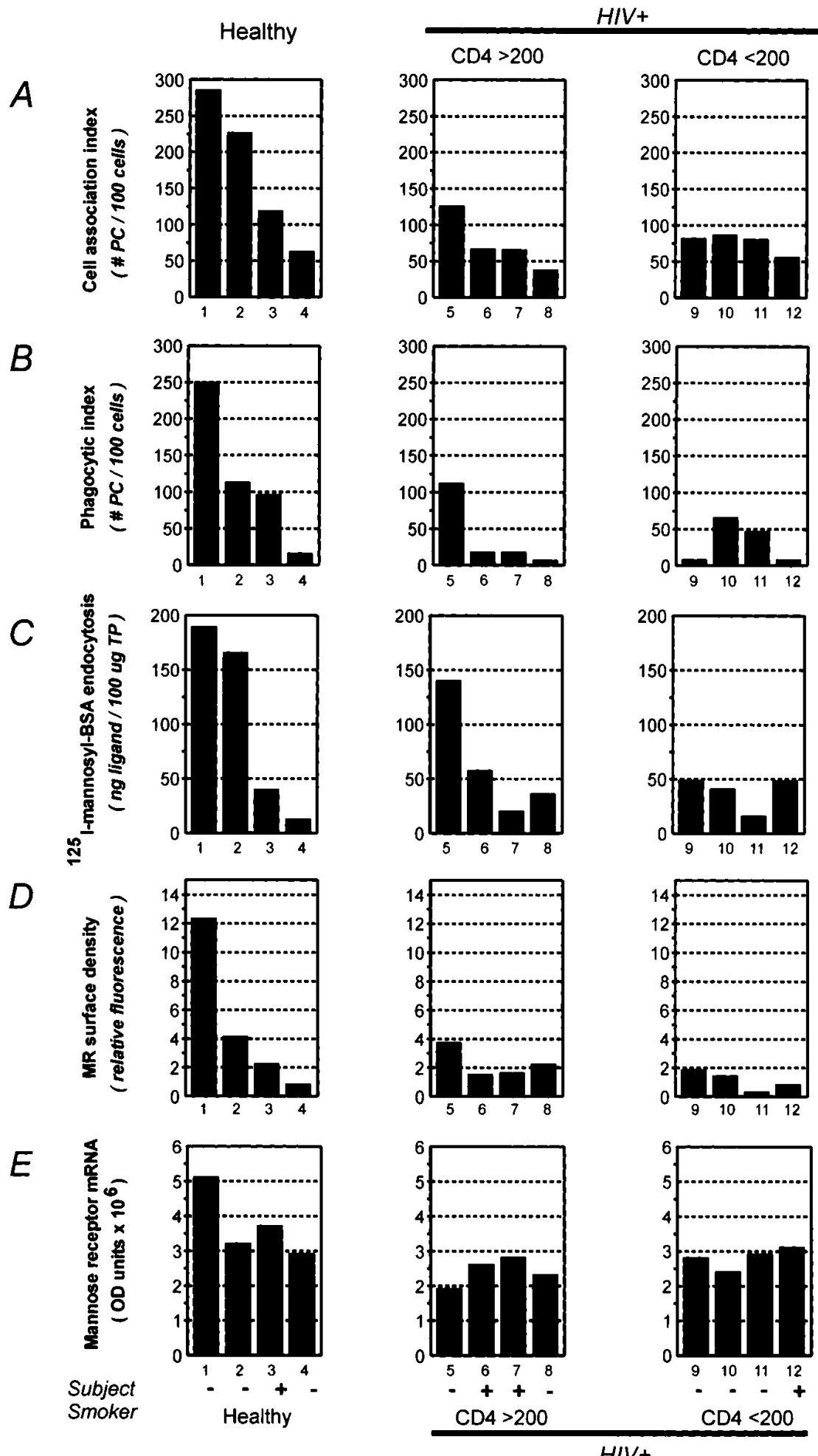

HIV+
Figure 6. Comprehensive evaluation of alveolar macrophage CAI $(A)$ and phagocytic index $(B)$ for $P$. carinii, and mannose receptor endocytosis $(C)$, surface density $(D)$, and mRNA levels $(E)$ for selected individuals. Data presented for four patients in each of three groups for whom all assays were performed as detailed in Methods. The smoking status is indicated for each subject. For each identified subject (1-12), each bar represents a mean of duplicate or triplicate measurements for each parameter assayed. duced $P$. carinii binding and phagocytosis. The reduced mannose receptor activity was due primarily to reduced surface receptor expression and in part to reduced mRNA levels, and not altered receptor affinity. As observed with $P$. carinii binding and phagocytosis, reduced mannose receptor-specific endocytosis and surface density was most profound in $\mathrm{HIV}^{+}$individuals with peripheral $\mathrm{CD}^{+} \mathrm{T}$ lymphocyte counts $<200$ cells $/ \mathrm{mm}^{3}$. Taken together, our results suggest that the observed reduction in $P$. carinii binding and phagocytosis by alveolar macrophages from $\mathrm{HIV}^{+}$individuals in part represents impaired mannose receptor-mediated recognition of this opportunistic pulmonary pathogen.

The observation that in vitro HIV-1 infection of alveolar macrophages reduced $P$. carinii binding and phagocytosis, and 

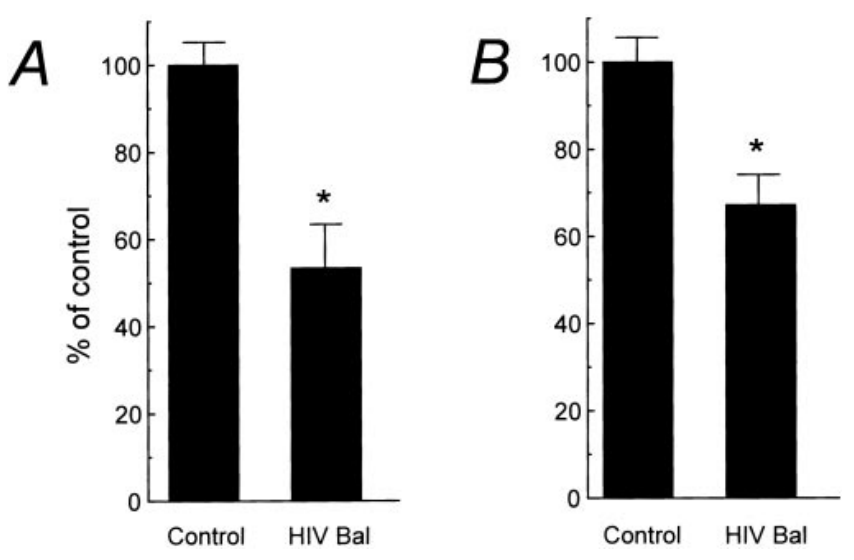

Figure 7. In vitro HIV-1 infection of alveolar macrophages from healthy individuals with a monocytotropic isolate $(\mathrm{HIV} \mathrm{Bal})$ reduced mannose receptor endocytosis $(A)$ and $P$. carinii binding and phagocytosis $(B) .{ }^{*} P<0.05$ compared with uninfected alveolar macrophages from healthy individuals. $n=4$.

reduced mannose receptor-mediated endocytosis supports a direct effect of HIV infection, or rather an effect of specific HIV structural or regulatory proteins. Recent reports indicate that HIV gene products may disturb host cell homeostasis as suggested by nef-mediated downregulation of CD4 receptor expression (48), $v p u$-mediated reduction in the CD4 receptor half-life (49), or downregulation of MHC-I molecules (50). HIV RNA is present in the cell-free BAL fluid supernatants of HIV-infected persons with $P$. carinii pneumonia (51) and in the absence of lung disease (reference 52 and Koziel, H., unpublished data), and thus the opportunity exists for direct interaction of HIV with alveolar macrophages. The mannoserich surface envelope glycoprotein (env) of HIV (HIV gp120) is recognized by the mannose receptor (53) and thus could sequester receptors and ligand to endosomal compartments. Macrophages incubated with mannose-rich zymosan display a similar downregulation of mannose receptor activity (54).

Alternatively, external regulatory molecules such as IFN- $\gamma$ may downregulate mannose receptor expression and endocytosis. Elevated levels of IFN- $\gamma$ have been measured in the BAL fluid of HIV-seropositive individuals $(55,56)$ and through downregulation of transcription (57) could in part account for the observations in this study. However, recent studies demonstrated that IFN- $\gamma$-mediated downregulation of macrophage mannose receptor expression was associated with enhanced phagocytosis of Candida albicans (58) and Saccharomyces cerevisiae (59). Thus, the influence of IFN- $\gamma$ alone is unlikely to account for the findings in this study.

Endotoxin (LPS), which downregulates mannose receptor expression (60), was unlikely to account for the observed reduction as the macrophages were cultured in endotoxin-free media, and there was no evidence for bacterial coinfection in any of the BAL specimens. The influence of medications was excluded in part by the absence of an in vitro effect of AZT, TMP-SMX, and pentamidine, although these observations do not preclude the possibility of an effect in vivo. Glucocorticosteroids, which upregulate mannose receptor (61), were not administered to any of the persons before bronchoscopy. The possibility that the reduced surface expression represented recently recruited peripheral blood monocytes is unlikely, as a distinct population of $\mathrm{CD} 14^{+} / \mathrm{CD} 45^{+}$cells were not identified by flow cytometry. The possibility that in vivo binding of $P$. carinii to macrophages may downregulate the mannose receptor in persons with active $P$. carinii pneumonia would not account for the reduced mannose receptor activity in persons at high risk but without pneumonia, and suggests other influences.

The mechanism for the observed downregulation of the macrophage mannose receptor may be multifactorial, likely reflecting direct or indirect influence of HIV infection, the transcriptional and posttranscriptional influences of local cytokine elaboration, and alterations in receptor recycling. Studies to delineate the potential role of these mechanisms in the observed phenomenon are currently the focus of active investigation.

The specific role and likely contribution of other molecules implicated in the interaction of $P$. carinii with macrophages, including $F_{c}(14,18)$, fibronectin $(62)$, and vitronectin (63) receptors, and the role of SP-A (64) and SP-D (65) were not examined. Although all cells were exposed to FCS, contaminating proteins and macromolecules derived from rat and mink cells which may influence $P$. carinii binding and phagocytosis need to be considered as possible confounding factors. The influence of coinfection with CMV was not directly investigated, and the relatively small number of persons investigated did not permit the determination of the influence of gender, tobacco use, and HIV risk factor in greater detail. The investigation of rodent-derived $P$. carinii interaction with human alveolar macrophages may have limited application to human disease. However, the absence of available methods to propagate human-derived $P$. carinii organisms does not allow this to be directly addressed. Finally, the observations in these in vitro studies may not represent the influences in vivo.

This investigation is the first to report that HIV infection may alter the cellular components of innate immunity $(24,32$, $33)$ in the lungs. Recognizing that mannose receptor-mediated phagocytosis of $P$. carinii represents only one component of a complex pulmonary host response to this organism, healthy individuals with low mannose receptor levels are likely not at risk for $P$. carinii pneumonia because acquired immunity in these individuals is otherwise intact. However, with the decline of $\mathrm{CD}^{+} \mathrm{T}$ lymphocytes to the critical level $<200$ cells $/ \mathrm{mm}^{3}$ which characterizes advanced HIV infection, downregulation of mannose receptor may represent the loss of an important clearance mechanism for $P$. carinii, and thus contribute to host susceptibility to pneumonia.

These data support the hypothesis that impaired alveolar macrophage mannose receptor-mediated recognition of $P$. carinii may in part account for the high incidence of $P$. carinii pneumonia in HIV-infected persons. Furthermore, with the ability of this pattern recognition molecule to recognize other pathogens (25), downregulation of alveolar macrophage mannose receptor may in part contribute to the development of other pulmonary infections frequently encountered in the HIV seropositive patient, including M. avium complex (66), Cryptococcus neoformans (67), and Mycobacterium tuberculosis (68). The identification of a specific defect in macrophage effector cell function provides the opportunity to develop novel agents directed at enhancing macrophage mannose receptor expression and function. Pharmacological enhancement of innate immune function may serve an adjunctive role in combination with specific antimicrobial agents currently used for HIVrelated lung infections. 


\section{Acknowledgments}

We are greatly indebted to the participation of all individuals who consented to bronchoscopy. Special thanks to Robert Garland, Nichole Pelletier, Jody Schock, Jean Lai, Bruce Ekstein, and Michael Chung for their dedicated and excellent technical assistance. We appreciate the careful review and helpful suggestions of Dr. Jerome E. Groopman.

This work was supported by U.S. Public Health Service Grant HL-43510 (H. Koziel and R.A.B. Ezekowitz), by the Pediatric AIDS Foundation (B.A. Kruskal), by a Massachusetts Thoracic Society and American Lung Association Research Grant (H. Koziel), and a Parker B. Francis Foundation Pulmonary Research Grant (H. Koziel).

\section{References}

1. Murray, J., and J. Mills. 1990. Pulmonary infectious complications of human immunodeficiency virus infection. Part I. Am. Rev. Respir. Dis. 141:13561372 .

2. Wallace, J.M., N.I. Hansen, L. Lavange, J. Glassroth, B.L. Browdy, M.J. Rosen, P.A. Kvale, B.T. Mangura, L.B. Reichman, P.C. Hopewell, and the Pulmonary Complications of H.I.V. Group. 1997. Respiratory disease trends in the Pulmonary Complications of HIV Infection Study cohort. Am. J. Respir. Crit. Care Med. 155:72-80.

3. Phair, J., A. Munoz, R. Detels, R. Kaslow, C. Rinaldo, and A. Saah. 1990. The risk of Pneumocystis carinii pneumonia among men infected with human immunodeficiency virus type 1. N. Engl. J. Med. 322:161-165.

4. Masur, H., F.P. Ognibene, R. Yarchoan, J.H. Shelhamer, B.F. Baird, W. Travis, A.F. Suffredini, L. Deyton, J.A. Kovacs, J. Falloon, et al. 1989. CD4 counts as predictors of opportunistic pneumonias in human immunodeficiency virus (HIV) infection. Ann. Intern. Med. 111:223-231.

5. Shellito, J.E., V.V. Suzara, W. Blumenfeld, J.M. Beck, H.J. Steger, and T.H. Ermak. 1990. A new model of Pneumocystis carinii infection in mice selectively depleted of helper T lymphocytes. J. Clin. Invest. 85:1686-1693.

6. Harmsen, A., and M. Stankiewicz. 1990. Requirement for CD4 ${ }^{+}$cells in resistance to Pneumocystis carinii pneumonia in mice. J. Exp. Med. 172:937-945.

7. Roths, J.B., J.D. Marshall, R.D. Allen, G.A. Carlson, and C.L. Sidman. 1990. Spontaneous Pneumocystis carinii pneumonia in immunodeficient mutant scid mice. Am. J. Pathol. 136:1173-1186.

8. Fels, A., and Z. Cohn. 1986. The alveolar macrophage. J. Appl. Physiol. 60:353-369.

9. Limper, A.H., J.S. Hoyte, and J.E. Standing. 1997. The role of alveolar macrophages in Pneumocystis carinii degradation and clearance from the lung. J. Clin. Invest. 99:2110-2117.

10. Barton, E., and W. Campbell. 1969. Pneumocystis carinii in lungs of rats treated with cortisone acetate. Am. J. Pathol. 54:209-236.

11. Harmsen, A.G., and W. Chen. 1992. Resolution of Pneumocystis carinii pneumonia in $\mathrm{CD}^{+}$lymphocyte-depleted mice given aerosols of heat-treated Escherichia coli. J. Exp. Med. 176:881-886.

12. Ezekowitz, R.A.B., D.J. Williams, H. Koziel, M.Y.K. Armstong, A. Warner, F.F. Richards, and R.M. Rose. 1991. Uptake of Pneumocystis carinii mediated by the macrophage mannose receptor. Nature. 351:155-158.

13. Hidalgo, H.A., R.J. Helmke, V.F. German, and J.A. Mangos. 1992. Pneumocystis carinii induces an oxidative burst in alveolar macrophages. Infect. Immun. 60:1-7.

14. Masur, H., and T.C. Jones. 1978. The interaction in vitro of Pneumocystis carinii with macrophages and L cells. J. Exp. Med. 147:157-170.

15. von Behren, L.A., and E.L. Pesanti. 1978. Uptake and degradation of Pneumocystis carinii by macrophages in vitro. Am. Rev. Respir. Dis. 118:10511059.

16. Pottratz, S.T., J. Paulsrud, J.S. Smith, and W.J. Martin. 1991. Pneumocystis carinii attachment to cultured lung cells by Pneumocystis gp120, a fibronectin binding protein. J. Clin. Invest. 88:403-407.

17. Forte, M., M. Rahelu, C. Stubberfield, L. Tomkins, A. Pithie, and D. Kumararatne. 1991. In-vitro interaction of human macrophages with Pneumocystis carinii. Int. J. Exp. Pathol. 72:589-598.

18. Taylor, M.B., M. Phillips, and C.S.F. Easmon. 1992. Opsonophagocytosis of Pneumocystis carinii. J. Med. Microbiol. 36:223-228.

19. Ezekowitz, R.A.B., K. Sastry, P. Bailly, and A. Warner. 1990. Molecular characterization of the human macrophage mannose receptor. Demonstration of multiple carbohydrate recognition-like domains and phagocytosis of yeasts in Cos-1 cells. J. Exp. Med. 172:1785-1794.

20. Stahl, P.D. 1990. The macrophage mannose receptor: current status. Am. J. Respir. Cell Mol. Biol. 2:317-318.

21. Taylor, M.E., J.T. Conary, M.R. Lennartz, P.D. Stahl, and K. Drickamer. 1990. Primary structure of the mannose receptor contains multiple motifs resembling carbohydrate-recognition domains. J. Biol. Chem. 265:12156-12162.

22. Radding, J.A., M.Y.K. Armstrong, E. Ullu, and F.F. Richards. 1989.
Identification and isolation of a major cell surface glycoprotein of Pneumocystis carinii. Infect. Immun. 57:2149-2157.

23. O'Riordan, D.M., J.E. Standing, and A.H. Limper. 1995. Pneumocystis carinii glycoprotein A binds macrophage mannose receptors. Infect. Immun. 63: 779-784.

24. Ezekowitz, R.A.B. 1992. The mannose receptor and phagocytosis. In Mononuclear Phagocytes. Rv. Furth, editor. Kluwer Academic Publishers, The Netherlands. 208-213.

25. Ofek, I., J. Goldhar, Y. Keisari, and N. Sharon. 1995. Nonopsonic phagocytosis of microorganisms. Annu. Rev. Microbiol. 49:239-276.

26. Fearon, D.T., and R.M. Locksley. 1996. The instructive role of innate immunity in the acquired immune response. Science. 272:50-54.

27. Salahuddin, S.Z., R.M. Rose, J.E. Groopman, P.D. Markham, and R.C. Gallo. 1986. Human T lymphotropic virus type III infection of human alveolar macrophages. Blood. 68:281-284.

28. Smith, P.D., K. Ohura, H. Masur, H.C. Lane, A.S. Fauci, and S.M. Wahl. 1984. Monocyte function in the acquired immune deficiency syndrome. Defective chemotaxis. J. Clin. Invest. 74:2121-2128.

29. Belsito, D., M. Sanchez, R. Baer, F. Valentine, and G. Thorbecke. 1984. Reduced Langerhans cell Ia antigen and ATPase activity in patients with the acquired immunodeficiency syndrome. N. Engl. J. Med. 310:1279-1282.

30. Roy, S., L. Fitz-Gibbon, L. Poulin, and M. Wainberg. 1988. Infection of human monocyte/macrophages by HIV-1: effect on secretion of IL-1 activity. Immunology. 64:233-239.

31. Bender, B., M. Frank, T. Lawley, W. Smith, C. Brinkman, and T. Quinn. 1985. Defective reticuloendothelial system Fc-receptor function in patients with acquired immunodeficiency syndrome. J. Infect. Dis. 152:409-412.

32. Holmskov, U., R. Malhotra, R.B. Sim, and J.C. Jensenius. 1994. Collectins: collagenous C-type lectins of the innate immune defense system. Immunol. Today. 15:67-74.

33. Sastry, K., and R.A.B. Ezekowitz. 1993. Collectins: pattern recognition molecules involved in first line host defense. Curr. Opin. Immunol. 5:59-66.

34. Hunninghake, G., J. Gadek, O. Kawanami, V. Ferrans, and R. Crystal 1979. Inflammatory and immune processes in the human lung in health and disease: evaluation by bronchoalveolar lavage. Am. J. Pathol. 97:149-206.

35. Armstrong, M.Y.K, and F.F. Richards. 1989. Propagation and purification of rat Pneumocystis carinii in short-term cell culture. J. Protozool. 36:24S-27S.

36. Armstrong, M.Y.K., and M.T. Cushion. 1993. Animal models. In Pneumocystis carinii Pneumonia. 2nd ed. P.D. Walzer, editor. Marcel Dekker, Inc., New York. 182-187.

37. Williams, D.J., J.A. Radding, A. Dell, K.-H. Khoo, M.E. Rogers, F.F. Richards, and M.Y.K. Armstrong. 1991. Glucan synthesis in Pneumocystis carinii. J. Protozool. 38:427-437.

38. Armstrong, M.Y.K., H. Koziel, R.M. Rose, C. Arena, and F.F. Richards. 1991. Indicators of Pneumocystis carinii viability in short-term culture. J. Protozool. 38:88S-90S.

39. Morganelli, P.M., R.A. Rogers, T.J. Kitzmiller, and A. Bergeron. 1995. Enhanced metabolism of LDL aggregates mediated by specific human monocyte IgG Fc receptors. J. Lipid Res. 36:714-724.

40. Greenspan, P., E.P. Mayer, and S.D. Fowler. 1987. Nile red: a selective fluorescent stain for intracellular lipid droplets. J. Cell Biol. 100:965-972.

41. Nicholson, J.D.A., and S.W. Browning. 1994. Ability of OptiLyse lysing fixing reagents to inactivate HIV-infected H9 cells in whole blood. J. Immunol. Methods. 168:283-284

42. Hoppe, C., and Y. Lee. 1983. The binding and processing of mannosebovine serum albumin derivatives by rabbit alveolar macrophages. J. Biol. Chem. 258:14193-14199.

43. Ezekowitz, R.A.B., J. Austyn, P.D. Stahl, and S. Gordon. 1981. Surface properties of Bacillus Calmette-Guerin activated mouse macrophages. Reduced expression of mannose-specific endocytosis, Fc receptors and antigen F4/ 80 accompanies induction of Ia. J. Exp. Med. 154:60-76.

44. Stahl, P., P.H. Schleshinger, E. Sigardson, J.S. Rodman, and Y.C. Lee. 1980. Receptor-mediated pinocytosis of mannose glycoconjugates by macrophages: characterization and evidence for receptor recycling. Cell. 19:207-215.

45. O'Riordan, T.G., R.P. Baughman, M.N. Dohn, and G.C. Smaldone. 1994. Lobar pentamidine levels and Pneumocystis carinii pneumonia following aerosolized pentamidine. Chest. 105:53-56.

46. Young, L.S. 1982. Trimethoprim-sulfamethoxazole in the treatment of adults with pneumonia due to Pneumocystis carinii. Rev. Infect. Dis. 4:608-613.

47. Yarchoan, R., R.W. Klecker, K.J. Weinhold, P.D. Markham, H.K. Lyerly, D.T. Durack, E. Gelman, S.N. Lehrman, R.M. Blum, and D.W. Barry. 1986. Administration of 3-azido-3-deoxythymidine, an inhibitor of HTLV-III/ LAV replication, to patients with AIDS or AIDS-related complex. Lancet. 1: 575-580.

48. Bensson, R., A. Sanfridson, J. Ottinger, C. Doyle, and B. Cullen. 1993. Downregulation of cell-surface CD4 expression by simian immunodeficiency virus Nef prevents super infection. J. Exp. Med. 177:1561-1566.

49. Willey, R., F. Maldarelli, M. Martin, and K. Strebel. 1992. HIV-1 vpu protein induces rapid degradation of CD4. J. Virol. 66:7193-7200.

50. Kerkau, T., I. Bacik, J.R. Bennink, J.W. Yewdell, T. Hunig, A. Schimpl, and U. Schubert. 1997. The human immunodeficiency virus type 1 (HIV-1) Vpu protein interferes with an early step in the biosynthesis of major histocompati- 
bility complex (MHC) class I molecules. J. Exp. Med. 185:1295-1305.

51. Lu, W., and D. Israel-Biet. 1993. Virion concentration in bronchoalveolar lavage fluids of HIV-infected patients. Lancet. 342:298.

52. Nakata, K., W.N. Rom, Y. Honda, R. Condos, S. Kanegasaki, Y. Cao, and M. Weiden. 1997. Mycobacterium tuberculosis enhances human immunodeficiency virus-1 replication in the lung. Am. J. Respir. Crit. Care Med. 155: 996-1003.

53. Larkin, M., R. Childs, and T. Matthews. 1989. Oligosaccharide-mediated interactions of the envelope gp120 of HIV-1 that are dependent on CD4 recognition. AIDS. 3:793-798.

54. Berton, G., and S. Gordon. 1983. Modulation of macrophage mannosylspecific receptors by cultivation on immobilized zymosan. Effects on superoxide-anion release and phagocytosis. Immunology. 49:705-715.

55. Fan, J., H.Z. Bass, and J.L. Fahey. 1993. Elevated IFN- $\gamma$ and decreased IL-2 gene expression are associated with HIV infection. J. Immunol. 151:50315040 .

56. Buhl, R., H.A. Jaffe, K.J. Holroyd, Z. Borok, J.H. Roum, A. Mastrangeli, F.B. Wells, M. Kirby, C. Saltini, and R.G. Crystal. 1993. Activation of alveolar macrophages in asymptomatic HIV-infected individuals. J. Immunol. 150:1019-1028.

57. Harris, N., M. Super, M. Rits, G. Chang, and R.A.B. Ezekowitz. 1992. Characterization of the murine macrophage mannose receptor: demonstration that the downregulation of receptor expression mediated by interferon- $\gamma$ occurs at the level of transcription. Blood. 80:2363-2373.

58. Marodi, L., S. Schreiber, D.C. Anderson, R.P. MacDermott, H.M. Korchak, and R.B.J. Johnston. 1993. Enhancement of macrophage candidacidal activity by interferon- $\gamma$. Increased phagocytosis, killing, and calcium signal mediated by a decreased number of mannose receptors. J. Clin. Invest. 91:2596-2601.

59. Raveh, D., B.A. Kruskal, J. Farland, and R.A. Ezekowitz. 1998. Th1 and Th2 cytokines cooperate to stimulate mannose-receptor-mediated phagocyto- sis. J. Leukoc. Biol. 64:108-113.

60. Shepherd, V.L., R. Abdolrasulnia, M. Garrett, and H.B. Cowan. 1990. Down-regulation of mannose receptor activity in macrophages after treatment with lipopolysaccharide and phorbol esters. J. Immunol. 145:1530-1536.

61. Shepherd, V.L., M.G. Konish, and P. Stahl. 1985. Dexamethasone increases expression of mannose receptors and decreases extracellular lysosomal enzyme accumulation in macrophages. J. Biol. Chem. 260:160-164.

62. Pottratz, S.T., and W.J. Martin. 1990. Mechanism of Pneumocystis carinii attachment to cultured rat alveolar macrophages. J. Clin. Invest. 86:16781683.

63. Neese, L.W., J.E. Standing, E.J. Olson, M. Castro, and A.H. Limper. 1994. Vitronectin, fibronectin, and gp120 antibody enhance macrophage release of TNF- $\alpha$ in response to Pneumocystis carinii. J. Immunol. 152:4549-4556.

64. Williams, M.D., J.R. Wright, K.L. March, and W.J. Martin, II. 1997. Human surfactant protein A enhances attachment of Pneumocystis carinii to rat alveolar macrophages. Am. J. Respir. Cell Mol. Biol. 14:232-238.

65. O'Riordan, D., J. Standing, K. Kwon, D. Chang, E. Crouch, and A. Limper. 1995. Surfactant protein D interacts with Pneumocystis carinii and mediates organism adherence to alveolar macrophages. J. Clin. Invest. 95:26992710 .

66. Bermudez, L.E., L.S. Young, and H. Enkel. 1991. Interaction of Mycobacterium avium complex with human macrophages: roles of membrane receptors and serum proteins. Infect. Immun. 59:1697-1702.

67. Bolanos, B., and T.G. Mitchell. 1989. Phagocytosis and killing of Cryptococcus neoformans by rat alveolar macrophages in the absence of serum. $J$. Leukoc. Biol. 46:521-528.

68. Schlesinger, L.S. 1993. Macrophage phagocytosis of virulent but not attenuated strains of Mycobacterium tuberculosis is mediated by mannose receptors in addition to complement receptors. J. Immunol. 150:2920-2930. 